\title{
A STUDY OF SCRAMBLE METHOD IN TEACHING ENGLISH FOR SECONDARY STUDENT'S WRITING SKILL
}

\author{
Suci Ariyani \\ Department of English Education, Samudra University \\ Langsa, Aceh, Indonesia
}

\begin{abstract}
In Indonesia secondary school, students are equipped with any English subject to arrange their own writing. In this case, writing is the one of difficult English skill for students. Because of that, to increase students writing skill teacher need a certain method in teaching writing. Based on student's ability in writing that also suitable with their grades, they were difficult to arrange the sentence to be good paragraph. To solve this problem several teachers had applied a method that called scramble sentence method. This study used qualitative research method with concept analysis method or library research. The data of this study came from eight articles related about scramble method to secondary student's writing skill. Data had analyzed from reading, reviewing, supporting and contra journal article and concluding. As the result, according to eight articles, the researcher found that scramble method was effective to increased student's writing skill. Based on the implementation of each article, scramble method helped students to write. It proven by the improvement of several writing aspects, such as topic sentence, supporting sentence, coherence, organization, generic structures, grammar, vocabulary, content, discourse, syntax, mechanic and language use. From the analysis, the research question of this study had answered.
\end{abstract}

Keyword: Scramble method, writing, library research

\section{INTRODUCTION}

Among of several English skills for students in the school, writing is the one of difficult English skill. According to Rahmawati (2016) most of Indonesian students have difficulties in writing skill that also happened to the students of junior high school MTs Negeri 2 Surakarta. This opinion was supported by other researchers, such as Afrizal (2016), Mukhlas and Nurbayanah (2014), Yuliana, Septy and Husna (2016), and Mudhisari (2017) they concluded that the students got some difficult in writing skill. This is caused by some factor, such as internal factors from the students themselves, in fact students skill in English are very poor and low especially in writing skill.

Based the problem above, it can be concluded that writing is a difficult English skill for students. According to several methods in teaching English for students especially teaching writing, the scramble method has been chosen by several teachers as the one of the teaching method used to improving their writing skill. There are some researches about teaching English with using scramble methods such as Rahmawati (2016), Andini, Nadrun and Budi (2016), Budianti and Rahmawati (2019) and Afrizal (2016). The researches had concluded to increase student's' writing skill, scramble is one of method that used to improve students' concentration and speed of thought. This method requires 
students to combine the right brain and the left brain (Huda, 2014). Scramble Method is a method that asks students to arrange random letter, words or sentence to be a logically sentence. Through the Scramble Method, the students can be trained to be creative in arranging random words.

Scramble method will give motivation, the students will be interested in learning process and also this method will makes students to be active (Huda, 2014) . Through Scramble method the students could be trained to arrange the sentence. This method was expected to be able to motivate the students to composite sentence. The students would arrange jumbled words, sentence or paragraph to be a clear meaning sentence.

\section{LITERATURE REVIEW}

\subsection{WRITING SKILL}

According to (Badger \& white, 2000) Writing in process approaches had seen as predominantly to do with linguistic skills, such as planning and drafting, and there is much less emphasis on linguistic knowledge, such as knowledge about grammar and text structure. Referring to, Harmer (2004) Writing had used for a wide variety of purposed produced in many different forms.

Based on the both statement it can be concluded that writing is an English skill which important for students needs in their academic or daily activity with a various purposes and form of writing. In our life we could not avoid that writing is one of necessary aspect in all of condition.

Cheung (2016) states that certainly, writing skills are include not only word choices, sentence variations, punctuation choices, and other linguistic tools for writing aspects such as cohesion and coherence, but also ways to structure and develop arguments at the micro and macro levels. It is need to create students creative thinking process that will be produce a good written based on daily or academic writing.

\subsection{ASPECT IN WRITING SKILL}

To know how far the skill of students writing was increased, teacher need to evaluate students written based on the several writing aspects. According to Brown (2001) several aspects of writing that would be evaluated for student's written as follows:
1. Content
2. Organization
3. Discourse
4. Syntax
5. Vocabulary
6. Mechanic

\subsection{THE APPLICATION OF SCRAMBLE METHOD IN ENGLISH WRITING CLASSROOM}

Scramble is a learning method that can improve student's concentration and speed of thought. This method requires students to combine the right brain and the left brain. In this method, they not only asked to answer the question, but also to guess quickly answer questions (Huda, 2014). This method asks students to arrange random letter, words or sentence to be a logically sentence. Through the Scramble Method, the students can be trained to be creative in arranging random letters, words or sentences. 


\section{Steps for applying scramble method:}

To function as it should, scramble method must follow the learning implementation procedures. Steps to teach with scramble method according to, Huda (2014) are :

1. Teacher present the material based on the topic

2. Distribute worksheets according to the example

3. Teacher gives duration to students to work on the problem

4. Students work on problem based on the duration specified by the teacher

5. Teacher check the duration of time while checking the students work.

\section{METHODOLOGY}

This research uses qualitative research design with concept analysis method or library research by using document analysis. Concept analysis basically defined as an activity were concepted to clarify their characteristic and relations with other concepts (Nuopponen, 2010). In this research, source of data will get from internet or nearest library. Data obtained by documents form article or journal related about scramble method to improve secondary student's writing skill.

\section{RESULTS}

Based on the data collection procedure, there are eight articles found by the researcher. Data would be analyzed by steps such as reading, reviewing, writing supporting and contra of journal article and concluding each other article. All of the articles are about improved students writing skill with used scramble method application for secondary students. The researches obtained were:

1. Afrizal, M. (2016) Improving Students' Writing Skill By Using Scramble Sentence Method. Journal Pendidikan Almuslim,

2. Andini, Nadrun and Budi (2018) "The effect of scrambled sentence technique in improving writing skill”,E-journal of English language society

3. Budianto \& Rahmawati (2019) "Scramble sentence method to teach writing descriptive text at the eighth-grade students of SMP N 26 Palembang".

4. Fatmawati, Mustaqum \& Juhansar (2018) "The implementation of jumbled sentences toward student's skill in writing report text".

5. Malinda, Sutarsyah \& Putrawan "Improving students writing ability in recount text writing through jumbled sentences at the first grade of SMA Kartikatama".

6. Mudhisari, L (2017) "The effect of teaching narrative text using scramble sentence towards students writing ability to the eight-grade students of SMP N 2 Papar Kediri academic year 2016/2017"

7. Mukhlas \& Nurbayan (2017) "The effectiveness of using scrambled sentence in teaching writing recount text"

8. Rahmawati, A (2016) Improving Students' Writing Ability On Recount Text By Using Scrambled Sentences (Classroom Action Research At The Eight Grade Students Of Mts N 2 Surakarta). Seminar Nasional Kajian Bahasa dan Pengajarannya $(K B S P) I V$. 


\section{1 DATA ANALYSIS}

Based on eight articles which the researcher reviewed, all the articles reached the findings that the scramble method is effective. However, in the researcher review, the strengths and the weaknesses on each article can be discussed.

For example, in article by Andini, Nadrun and Budi (2018) in her research with title "The effect of scrambled sentence technique in improving writing skill", the strength can be found that this article explained how they collected data by the posttest and pretest also the way of treatment. The researcher also gave an example for student's written topic "Holiday to Yogyakarta" and enclosed the improvement of grammatical structure based on the topic.

Despite these strengths, there is a weakness; even if the article concluded that scramble method was effective but this article did not give the example of jumbled sentences in their research that would be arranged for students to be a good recount paragraph. It makes readers not understand how the practice material with mixed sentences that would hand out for students.

It supported with research by Rahmawati (2019) "Improving students writing ability on recount text by using scrambled sentence (Classroom action research at the eighth-grade students of MTs N 2 Surakarta)" that also concluded scramble method could improve students writing skill in recount paragraph but different with a research by Andini, Nadrun and Budi (2018) this research enclosed well about how the researcher implementation scramble sentence method to students writing skill, especially recount paragraph.

Both articles showed the topic of recount text. At the pretest students asked to built 3 paragraphs that consisted minimal 5 sentences with topic "Unforgettable experience", this topic was not far from a topic that given by Andini, Nadrun and Budi (2018) "Holiday to Yogyakarta". The result of pretest on both articles was same; students got difficult in grammatical and just copied the example from researcher. After treatment with scramble method sentence students writing skill had improved.

The result that student's scores in writing recount paragraph increased by scramble method also supported by a research from Malinda, Sutarsyah \& Putrawan entitled "Improving students writing ability in recount text writing through jumbled sentences at the first grade of SMA Kartikatama". Even if this research showed good data in posttest and pretest, aspects of scoring and aspect improvement also explain clearly but as a weakness, this research did not explain how steps of implementation scramble sentence method in treatment. It is not different with a research by Mukhlas \& Nurbayan entitled (2017) "The effectiveness of using scrambled sentence in teaching writing recount text", as the same research that focused to recount text, this research also got same result that scramble method was help students to write. The strength of this research is researcher showed clearly about all of the data but same with a research by Malinda, Sutarsyah and Putrawan, this research did not explain how the implementation of scramble sentence method in the class room.

Besides, there is a different method among both research, a research by Mukhlas and Nurbayan (2017) used experimental method design with experimental group and control group also showed writing aspects that had improved student's writing skill but a 
research by Malinda, Sutarsyah and Putrawan used one group pretest-posttest design and did not show the aspects of writing that would be improved by scramble sentence method.

Additionally, research that supported scramble sentence method was effective to students writing recount text, also there are 2 researches that focused improved students writing text in descriptive text. The researches by Budianto \& Rahmawati (2019) with the title "Scramble sentence method to teach writing descriptive text at the eighth-grade students of SMP N 26 Palembang". And a research by Afrizal (2016) with his title "Improving students writing skill with using scramble sentence method". Both of this research concluded that scramble sentence method was help students to learn descriptive text. As a weakness both of this research did not showed how the researcher conduct the treatment through scramble sentence method and did not gave an example of practice materials for students but among of both research, research by Afrizal is simpler, it is because this research used qualitative method as the only one different method based on eight articles.

The treatment that conducted in Afrizal's articles did by teacher as collaborator. To collect the data researcher wrote observation checklist, field note and analyzed the students learning result by students rating aspects in cycle 1 but the result students improvement in cycle 2 was not showed in form of rating scores in this article. If compares with a research by Budianto \& Rahmawati, (2019) this article enclosed several aspects of writing that was improved through scramble sentence method, different with a research by Budianto \& Rahmawati (2019) that did not showed the aspects of writing scores.

Even both of these research got same result but they have different method. A research by Budianto \& Rahmawati, (2019) had used quantitative research with experimental research. Even this research did not showed aspects scores clearly but this research showed a good explanation to prove the effectiveness of scramble sentence method by each other scores in control group and experimental group.

Based on the various articles about scramble sentence method in recount text and descriptive text, also there is a research by Mudhisari (2017) entitled "The effect of teaching narrative text using scramble sentence towards students writing ability to the eight-grade students of SMP N 2 Papar Kediri academic year 2016/2017" that focused to improved students writing skill in narrative text. Not only narrative text, another researcher also comes from Fatmawati, Mustaqum \& Juhansar (2018) entitled "The implementation of jumbled sentences toward student's skill in writing report text" that focused to improved students writing skill in report text. Same with other research, both of this research also supported that scramble method was effective to student's writing skill.

There are weaknesses in both of article. The weaknesses are the researcher did not explain how they applied the scramble sentence method to students and how the kind of practice material but research by Fatmawati, Mustaqum \& Juhansar (2018) showed the condition along teaching and learning process, if compared with an article by Mudhisari (2017), she did not explain about that. Aside from that research by Fatmawati, Mustaqum \& Juhansar (2018) also contained the students writing aspects that were being student's aspects scores to know anything that had improved by scramble method but the research by Mundhisari did not. 
Different with Mudhisari, a research by Fatmawati, Mustaqum \& Juhansar (2018) used qualitative and quantitative research design. To get the data Fatmawati, Mustaqum \& Juhansar (2018) obtained result by observation, interviewed, and tests. The result of each activity also enclosed and explained well. Same with a research by Mudhisari (2017) that enclosed data by charts and table, both of this research just has a different by the way of data collected.

Among of various research that was analyzing, compare and discuss, most of research did not explain how the implementation of scramble sentence method in the classroom, just the research by Rahmawati (2019) "Improving students writing ability on recount text by using scrambled sentence (Classroom action research at the eighth-grade students of MTs N 2 Surakarta)" and a research by Andini, Nadrun and Budi (2018) in her research with title "The effect of scrambled sentence technique in improving writing skill", that contained the way of researcher applied scramble sentence method.

Besides that, even if other research did not enclosed their steps in scramble method but two researches told the condition of teaching leaning process when she did pretest, treatment till posttest, such as a research by Malinda, Sutarsyah \& Putrawan entitled "Improving students writing ability in recount text writing through jumbled sentences at the first grade of SMA Kartikatama". and the research by Fatmawati, Mustaqum \& Juhansar (2018) entitled "The implementation of jumbled sentences toward student's skill in writing report text".

While four other researches did not show the implementation of scramble method and the condition of classroom. The research are Mudhisari (2017) entitled "The effect of teaching narrative text using scramble sentence towards students writing ability to the eight-grade students of SMP N 2 Papar Kediri academic year 2016/2017", Budianto \& Rahmawati (2019) with the title "Scramble sentence method to teach writing descriptive text at the eighth-grade students of SMP N 26 Palembang". Afrizal (2016) with his title "Improving students writing skill with using scramble sentence method" and a research by Mukhlas \& Nurbayan entitled (2017) "The effectiveness of using scrambled sentence in teaching writing recount text",

Even if there are two studies that enclosed the implementation of scramble method in their articles, two studies just enclosed the condition of classroom when treatment was held and four studies did not enclosed both of that, but there is no research that told the readers how the practice materials or the example of jumbled sentence that would be arranged by students.

Based on various differences between articles, eight articles above found the same result about scramble sentence method. They concluded that scramble method was effective to improved students writing skills. It can be proved by the mean scores of students in each article that had a significant improvement after treatment with scramble method. 


\subsection{ENGLISH WRITING SKILL ASPECTS THROUGH THE METHODE}

Based on analyzed by eight articles, scramble method had improved students writing skill by several aspects of writing. The aspects are based on the table bellow

Table. 7 Improvement on writing skill aspects by the scramble method

\begin{tabular}{|l|c|}
\hline \multirow{4}{*}{ The method } & Writing skill aspects \\
\hline \multirow{4}{*}{ Scramble sentence method } & Topic sentence \\
\cline { 2 - 3 } & Supporting sentence \\
\cline { 2 - 3 } & Coherence \\
\cline { 2 - 3 } & Organization \\
\cline { 2 - 3 } & Generic structures \\
\cline { 2 - 3 } & Grammar \\
\cline { 2 - 3 } & Vocabulary \\
\cline { 2 - 3 } & Content \\
\cline { 2 - 3 } & Discourse \\
\hline & Syntax \\
\hline
\end{tabular}

The writing aspects that improved students writing skill such as topic sentence, supporting sentence, coherence, organization, and generic structures had supported by a research from Fatmawati, Mustaqum \& Juhansar (2018) entitled "The implementation of jumbled sentences toward student's skill in writing report text". In this article, students score improved based on those five writing aspects. The mean score in last posttest concerning topic sentence was 3.79 that improved from pretest 2,96, supporting sentence was 3.71 that improved from pretest 2.75 , coherence was 3.46 that improved from pretest 3.17 , organization was 3.75 that improved from pretest 3.13 and generic structures 4.17 that improved from 3.00.

Same with a research from Fatmawati, Mustaqum \& Juhansar, a research by Andini, Nadrun and Budi (2018) with title "The effect of scrambled sentence technique in improving writing skill" also contained organization as writing aspects that had improved by students. In this article, not only organization but also the student's mean score had improvement based on grammar and vocabulary as writing aspect. Based on the posttest in experimental group, there are four students got maximal score in grammar $(13 \%)$, six students get maximal score in organization $(20 \%)$ and five students get 
maximal score in vocabulary (16\%). It improved from the result of pretest that no student got maximal score in grammar, only one student got maximal score in organization and only one student got maximal score in vocabulary.

The research from Afrizal (2016) with his title "Improving students writing skill with using scramble sentence method" is not far from research by Andini, Nadrun and Budi. Afrizal also used vocabulary and organization to measure students writing skill. Apart from these two aspects, Afrizal also used content, discourse, syntax and mechanics as writing aspects. Unfortunately, this article did not explain how the improved mean score based on each other aspects. The score of aspects just showed in first cycle and did not calculate to be the mean score.

The last, a research that have same writing aspects with Afrizal comes from Malinda, Sutarsyah \& Putrawan entitled "Improving students writing ability in recount text writing through jumbled sentences at the first grade of SMA Kartikatama". Aspects of writing in this article are content, organization, vocabulary, language use and mechanic. In posttest, students score concerning content improved from 18.48 to 23.22 , students score concerning organization improved from 12.00 to 14.06 , students score concerning vocabulary improved from 12.24 to 14.02 , students score concerning language use improved from 13.64 to 18.24 and studssents score concerning mechanic improved from 3.02 to 3.12 .

According to four articles above, there were various writing aspects used to measure students writing skill after treatment with scramble sentence method. Apart from that, four articles other did not contained what writing aspects they used to get the result of students improvement

\section{CONCLUTION AND SUGGESTION}

Scramble method in this study was analyzed, compared and discussed based on each other articles. In this study, the kind of scramble method was chosen by researcher is scramble sentence method. As we know that scramble sentence method is an activity to rearrange the jumble sentence to be a paragraph.

Besides that, this study just obtained articles which conducted in secondary students. Secondary students are categorized from first grade of SMP to first grade of SMA that also stated in the title. This is suitable considering the students of secondary school need to learn good writing with properly method. Depend on that, all of articles collected are about scramble sentence method to increase student's writing skill. As the result researcher found, with scramble method students was more interested, creative, confidence to write and their score also increased. This method helped the researcher when teaching and learning process.Based on analysis of this previous library research, the findings are resulted based on the proposed research question, the conclusion can be presented as follows :

1. By several steps of implementation and routine treatment with the scramble sentence method, it can answer the first research question of this study, that scramble method affected to students interactive and interesting to write, be more active, be more independent to write, and could improve students mean score in certain material.

2. Students writing improvement measured through several writing aspects such as topic sentence, supporting sentence, coherence, organization, generic structure, 
grammar, vocabulary, content, discourse, syntax, language use and mechanic. It answered the second research question of this study "What writing skill aspects are affected by the scramble method for secondary student's writing skill?".

To increase student's writing skill the teacher should have a certain method with different way from usual method. In the classroom, students need something new to make them be happy along of teaching and learning process. The method should implementation with fun, enjoy, and requires students to work in cooperative also effective to improve student's confidence.

The students should learn with focus to material, follow the instruction of teacher and practice their writing skill in the home. As an important aspect of writing, students should mastering grammar that related to the text. It can minimize the writing errors by students.

To make a good research, researcher should proven the result with how the implementation of method, how the condition of classroom and what the aspects of scoring. It will make the research be better and will not the readers confused. Besides that, the researcher hope that this research will help another researchers as reference for everyone that faced same problem about students writing skill

\section{REFERENCES}

Afrizal, M. (2016) Improving Students' Writing Skill By Using Scramble Sentence Method. Journal Pendidikan Almuslim, Retrieved on October 20, 2019. From https://www.researchgate.net/publication/

Ariyanti (2016) The Teaching of EFL Writing in Indonesia. Dinamika Ilmu. Retrieved on September 1, 2020 From https://www.researchgate.net/publication/

Brown, H. D (2001) Teaching In Principles An Interactive Approach To Language Pedagogy. New York: Longman,Inc. Retrieved on Augustus 15, 2020. From https://www.researchgate.net/publication/

Bowen, G. (2009) Document Analysis as a qualitative research method. Western Carolina University. DOI: 10.3316/QRJ0902027

Broughton, G., Brumfit, C., Fravell, L., Hill, P., Pincas, A., (2003) Teaching English as Foreign Language. London : Raudledge. Retrieved on February 5, 2018. From https://teaching-english-as-foreign-language-routledgeeducation-books-pdf

Cheung, Y.,L (2016) Teaching Writing. Nanyang Technological University. DOI: 10.1007/978-3-319-38834-2_13

Hanafiah, Nanang \& Suhana. C (2009) Konsep dan pembelajaran. Bandung: PT. Rifika Aditama. Retrieved on February 7, 2020. From https://play.google.com

Harding, T. S, \& Whitehead, D. (2013) Analysing data in qualitative research. University of Canterburry and Flinders University. Retrieved on February 7, 2020. From https://www.researchgate.net/publication/255950505 
Harmer, J. (2004) How To Teaching Writing, London : Person Education Limited. Retrieved on Augustus 15, 2020. From www.pdfdrive.com

Huda, M (2014) Model-model pengajaraan dan pembelajaran. Yogyakarta : Pustaka Belajar.

Ivone, F. M. (2005) Teaching English As A Foreign Language In Indonesia: The Urge To Improve Classroom Vocabulary Instruction. Journal Universitas Negeri Malang. Retrieved on Augustus 15, 2020. From https://www.researchgate.net/publication/255950505

Lopez, V., \& Whitehead, D. (2012) Sampling data and data collection in qualitative research. Australia national University and Flinders University.

$\begin{array}{lllll}\text { Retrieved on } & \text { February } & \text { From }\end{array}$ https://www.researchgate.net/publication/255950308

Mason, Jennifer (2002) Qualitative Researching, Second edition. London, Thousand Oaks, New Delhi : Sage Publitions. Retrieved on February 7, 2020. From www.pdfdrive.com

Nuopponen, A (2010) Methods of concept analysis - a comparative study. Professional Communication Knowledge Management Cognition. Retrieved on September 12 , 2020. From http://lsp.cbs.dk

Rahmawati, Any (2016) Improving Students' Writing Ability On Recount Text By Using Scrambled Sentences (Classroom Action Research At The Eight Grade Students Of Mts N 2 Surakarta). Seminar Nasional Kajian Bahasa dan Pengajarannya (KBSP) IV. Retrieved on July 8, 2020. From https://www.researchgate.net/publication/259828893

Sugiyono (2012) Metode penelitian kuantitatif, kualitatif dan R\&D. Bandung : Alfabeta

Wach, E (2013) Learning about Qualitative Document Analysis. Institute of Development Studies. Retrieved on September 12, 2020. From https://www.researchgate.net/publication/259828893

Zaim, M. (2017) Implementing Scientific Approach to Teach English at Senior High School in Indonesia. Asian Social Science. Retrieved on Augustus 15, 2020. From https://www.researchgate.net/publication/259828893

Zemach, D. E \& Islam, C (2005) Paragraph Writing : From Sentence To Paragraph, New York : Macmillan. Retrieved on Augustus 15, 2020. From www.pdfdrive.com

Zeid, M (2004) Metode Penelitian Kepustakaan. Jakarta :Yayasan Obor Nasional. Retrieved on Augustus 15, 2020. https://play.google.com 